\title{
International beauty pageants and the construction of hegemonic images of female beauty
}

\author{
H. I. G. C. Kumara" and R. A. W. D. Jayawardhana \\ Department of Geography, Faculty of Humanities and Social Sciences, University of Ruhuna, Matara, Sri Lanka.
}

\begin{abstract}
Binaries like 'beauty/ugliness' or 'fair/dark' are ideological images driving the world market for beauty products. How are these images created? How far is the process of construction of these images influenced by socio-political and economic hegemonies? This paper addresses these research questions by deploying a qualitative dominant 'Mixed Research Methodology' and 'Inductive Research Approach'. The paper is based on secondary data on titleholders of a major beauty pageant held during the 50 year period from 1967 to 2017 . The data was analyzed using the Critical Discourse Analysis (CDA) method. The research discovered that $68 \%$ of titleholders are from peripheral/semi-peripheral countries such as India and Venezuela. Further, the researchers found that the physical features of these non-European titleholders from the peripheral states closely resemble western Caucasian 'white' woman, conforming to ideal standards of western feminine beauty. On the other hand, ironically, $95 \%$ of branded beauty products are manufactured and distributed by multinational companies with headquarters in developed countries. Accordingly, the research concludes that the women chosen as the world's most beautiful females display core characteristics of 'stereotypical western feminine beauty standards' and thereby, resemble a 'fantasy model of feminine beauty' conceptualized by a regime of 'white men', projecting its economic and political influence on the world stage. The fact that most titleholders are chosen from peripheral/semi-peripheral countries may be driven by a capitalist commercial project in which economies in the world dominant core countries have created a lucrative market for their beauty products in peripheral countries. Thus, this paper argues that the ideology and practice of international beauty pageants are shaped by the twin processes of global capitalism and world cultural-political hegemony.
\end{abstract}

Keywords: Beauty, international beauty pageants, Capitalism, hegemony.

\section{INTRODUCTION}

'Knowledge' and 'Ideologies' are socially constructed (Deutscher, 2014; Dubuisson, 2003; Syrotinski, 2007), ultimately in keeping with the social, political and economic interests of the ruling elites (Stoddart, 2007; Elden, 2016). The binary categories such as 'beauty/ ugliness' or 'fair/ dark' are among these ideological constructs shaping the identities and consumption behavior of the masses (Jameson, 2009). 'Beauty' is associated with appearance- physical/facial attractiveness or 'good-looks'- and it is commonly understood that most human beings wish to be physically attractive. Hence, this research focuses on two related questions: How is the concept of 'beauty' created? How have cultural, political and economic hegemonies contributed to and ultimately benefit from the process of creating these images?

\section{REVIEW OF LITERATURE}

The theoretical framework of this study is based on the argument that 'models of feminine beauty' or 'perfect female body image' have been appropriated into a global agenda in which these constructed images and related ideologies create a site for capitalist market forces and related global power structures.

"Corresponding author (chamindakumara03@yahoo.com; (iD https://orcid.org/0000-0001-7491-1796 ) 


\section{Feminism and the image 'Female Beauty'}

The feminist philosopher Simone de Beauvoir, in her volume The Second Sex, stated that 'one is not born but becomes a woman' and women are confined to certain roles in society with limited opportunities and circumscribed social status (de Beauvoir, 1949-2014). Further, "appearance is one of the technologies of gender and beauty is a gender related category" says Tseëlon (1993) in the paper The ideology of beauty. The writer further explains that,

"in a society where sexual difference forms part of its dominant ideology, men and women are bound to occupy different positions on the attractiveness dimension. Looks may be important for the man, but they are consequential for the woman: both in terms of how others value her, and how she values herself" (Tseëlon, 1993: p. 319).

According to Lacan, female is a 'visible object' and from the childhood she sees herself in a mirror where she realizes an 'outside appearance' imposed upon her (Sturken \& Cartwright, 2001). Further, the male observation of the female body is linked with this mirror stage theory, which means 'femininity' is socially constructed and the 'feminine object' is an object of desire for males (Sakar, 2014). As explained by many feminist scholars, 'ideology of beauty', which reproduces power on female bodies, is socially constructed and that is shaped by political and economic agendas (Tseëlon, 1995; Bordo, 2004; Grosz, 1994; Butler, 1993; Weitz, 1998).

"To the extent that the beauty model defines and values the woman through her appearance, it essentially regards her natural, bare, and uncontrolled body as a stigma, as ugliness-something to disguise, to modify, to improve. Thus, the woman is placed in a no-win situation. She is expected to embody a "timeless" cultural fantasy that is removed from the diverse and changing world of the living. But her special beauty is not really innate, and it takes a lot of effort to maintain. The effort to control the body is evidenced by the proliferation of a "weight control" culture, and cosmetic surgery" (Tseëlon, 1993: p. 319).

The so-called 'fantasy female body image' includes being fair, slim, wrinkleless, flawless etc., and these false ideals of body perfection are carried to the world through visual arts, media, science, technological innovations and also literature (Karacan, 2007). 'Hegemonic beauty ideology' is a 'myth' based on the European (AngloSaxon) values. This myth of beauty of female body has been used as a tool to control females (Wolf, 2013; Karacan, 2007). Therefore, some feminist scholars have identified female beauty as 'Ideological State Apparatus (ISA)' which functions by violence (Althusser, 1977; Butler, 1993). As an ideological tool, ISA defines the formation of power in a society.

Since there are huge gaps between physical appearance of natural unmodified female body and ideologically defined and valued appearance of women, only a few females can represent physical standards of socially constructed ideal of beauty. Thus, women tend to spend more time, energy, money and emotional resources in the futile effort to modify, improve and change their natural body/looks to correspond with these ideal beauty standards (Forbes et al., 2007). From early childhood, western beauty standards have been fantasized and imposed on females through cultural norms, visual arts, movies, novels, fairytales and even toys like Barbies (Karacan, 2007). As Synnott (1990) argued, sometimes innocent fairy tales are able to create the 'bad and ugly' fantasy and so-called ideology of female beauty in the child's mind.

"The beauty mystique is rooted not only in physiognomy and philosophy, linguistics, ethnic relations, war and criminology, but also in our literary heritage. Our fairy stories imbue children with the mystique. In Grimm's story, 'Cinderella', it is the remarkably beautiful and amazingly good Cinderella who wins the heart of the prince, in 'Beauty and the Beast', Beauty, who is both good and intelligent enough to see through ugliness, breaks the spell over the beast, which promptly turns into a handsome prince. The moral of the stories is not only that virtue triumphs, but so does beauty. All of these stories exemplify the beauty mystique, and socialize children into the cosmic value and practical utility of beauty" (Synnott, 1990: p. 57).

According to fairytales, beautiful women are characterized with shiny long hair, thin body, and very fair skin and thus, together with their being morally good and sweet they win the heart of a powerful prince/ man (Karacan, 2007). Then the question arises as what happens to others, those who are considered physically less attractive on the scale of so-called beauty standards or have not modified/improved their natural looks to match these fantasy beauty ideals. Will they, despite their good heart and sweet selves, hold a chance against those who are 'physically attractive'? The 'ugliness/dark skinned' usually associates with demons/devils or something 
bad and evil in fairy tales. This phenomenon, "physical beauty is believed to symbolize inner moral or spiritual beauty or goodness, so too physical ugliness is believed to symbolize an inner ugliness or evil" (Synnott, 1990: p. 56). Simply, such ideological construction of beauty has emotionally charged a majority of females from across the globe, especially ones in non-European regions (Cheng, 2000), to believe in the myth that "beauty/ fair skinned is an asset and ugliness/dark skinned is a stigma (Tseëlon, 1993). Considering that radical feminist discourse has identified female beauty ideology as one of the main factors contributing to gender inequality (Forbes et al., 2007), the myth of ideal beauty has emerged as a violent backlash against feminism in general (Wolf, 2013).

Another argument of feminists is that the "beauty myth' has contributed to cause unusual competition among women in the contemporary world that act as a barrier to achieve gender equality. Based on the beauty myth, females have divided categories of age, weight, color, youth etc., and beauty is creating an invisible 'class' among women. This in turn leads to marginalize a majority of females in the world (Wolf, 2013; Karacan, 2007). Therefore, feminist discourses have opposed and criticized the creation of 'female image, body and beauty' as an instrument of discrimination and harassment against women (Sakar, 2014).

Most importantly, the questions arise here as to: Who created this female beauty ideology? For what purposes? Are there any hidden agendas behind this? This, in turn, draws the researchers' attention to the nature of capitalism and consumerism (Karacan, 2007; Featherstone, 1982; Baudrillard, 2016).

\section{Capitalism \& Consumerism}

At present, neoliberal capitalism drives global economic systems (Hancké et al., 2008; Muller, 2007; Stark, 2007). The development of capitalism both as a market and economic force as well as an ideological domain has been static and hegemonic throughout its history. Static development of capitalism has abolished optional economic or market-oriented ideologies and that has led to monopoly of capitalism in controlling every aspect of human life. In this context, ideals of capitalism are being emphasized as 'universal' and crude desires of capitalist political economy is being stated as 'natural'. However, as many scholars argue, a capitalist economic system produces unequal economic development (Foster, 2001; Foster et al., 2011; Li, 2009).

'Consumerism' or 'the propagation of consumer tastes and desires' is directly linked with capitalist ideologies (Bauman, 2004; Micheletti \& Stolle, 2008) since a consumer society has to be developed to promote and maintain the capitalist world order (Marcuse, 2013). From the 1990s, 'female beauty ideology' has often been used in the capitalist system to develop a consumer society for beauty care products.

"The media in the early 90's used to be means of reporting and broadcasting largely news and songs, films, music and less of product advertisements. The products like ${ }^{* * * *}$ detergent or ${ }^{* * * * *}$ soap remained famous women's foray to be advertised during that era. The media and the pattern of advertisements has entirely changed in the post globalized era and it has become a vibrant mode and tool to shape, mould and change public opinion and create markets and demand for different products by projecting slim, trim, sculpted women bodies like a commodity. Be it homecare products, beauty products, telecommunication, IT products/computers, gizmo, food or lingerie, the woman body has been used unsparingly to advertise and market merchandise. In order to sell products, a reconstructed image of women with modified sculpted looks is presented before masses to influence their perception of an ideal women rendering the women commodity in the process. Print and visual media by projecting commoditizing, commercializing and reconstructing women image deceives the women as to what is her real image: one projected in the media or one she herself carries or the one prescribed by normative societal structure" (Sarkar, 2014: p. 54).

The consumer culture proposes females to believe in 'beauty image' as something which should be maintained and cherished throughout their lifetime, and for that, they can use different types of beauty products (Karacan, 2007). As Featherstone (1982) and Baudrillard (2016) highlighted, consumer society is a capitalist economic 'trap' which is based on hedonistic and narcissistic thought. Further, capitalist social structure creates 'socioeconomic classes' while it processes as a mechanism. As stated by Veblen (1899-2005) in his Trickle-Down Theory, 'fashion is practiced in the upper classes and imitated by the lower classes' and this ideology has been used in the capitalist world order to create markets for different types of beauty products. With the rise of these capitalist economies and globalization many aspects, including female beauty ideals of western culture, have been elated by the rest of the world, hence, the discourse of hegemonic power and core-peripheral dependency provides insight to understand non-European women's quest for Eurocentric female beauty ideals as standards. 
Discourse of 'hegemonic power and core-peripheral dependency'

Dependency, postcolonial and postmodern theories have mostly explained the nature of cultural, political and economic hegemonies which lead to unequal global social and economic processes based on political and economic hegemonic power of capitalist countries (Fewel, 1981; Desai \& Potter, 2014).

The radical dependency theory has conceptualized the resource and capital flow from 'peripheral' countries (less developed countries) to the 'core' countries (developed countries). It has demonstrated that this flow significantly contributes to world development processes which result in underprivileged poor states while the wealth of rich states is enhanced. Hence, the 'core' is developed because of the 'periphery' while the 'periphery' becomes peripheral because of accumulation in the 'core' (Costantinos, 1998; Sekhri, 2009). According to Conway \& Heynen,

"Dependency theory emerged as a critical lens through which the history of Latin American development, marginalized as it was by Western hegemony, could be better understood; the 'development of underdevelopment', no less" (Conway \& Heynen, 2002: p. 97).

According to postcolonial theories, 'western structures of knowledge' are imposed on southern peripheral contexts identifying western knowledge as scientific and, therefore, superior to indigenous knowledge systems. These 'best constructions' sometimes become 'ideological obstructions' in developing contexts since these are based on western 'autonomy' and 'hegemonic power' (Brydon, 2004; d'Hauteserre, 2004). According to postcolonial perspectives, historical global domination by Europeans and the USA since 1945, has had an influence on contemporary political, socio-economic, and psychological aspects of southern peripheral countries (Hall \& Tucker, 2004; Ziai, 2011). This form of 'ideological hegemony' has assisted in maintaining southern peripheral countries as a depending periphery in socio-cultural terms (Dirlik, 1994). Therefore, postcolonial theorists have criticized western forms of socio-cultural and economic domination, as a barrier to the development process of marginalized nations or communities (Krishna, 2009).

Political and economic dominations of the West have created a 'cultural hegemony'. Capitalist countries and ruling class in them (the bourgeoisie) use and create cultural values and norms to continue their powers to maintain their privileged dominant status (Adamson,
1983) and hegemonic culture standardizes its own sociocultural values/norms to maintain the status quo. As a result, 'image of life' viewed by majority of people represents super structural ideologies and this normative 'image of life' is further maintained by people from the periphery (Salamini, 2014). In other words, cultural hegemony is produced and reproduced by the dominant class following their own desires for their needs and cultural assets (Aronowitz, 2016).

In the globalized world, international beauty pageants hold a prominent place and they have been doing so for a considerable period of time. Images of the most beautiful females are celebrated at these events. While some people enjoy international beauty pageants, many feminists and social activists have criticized them as reflections of 'ugly globalization' and cultural imperialism (Hoad, 2004). In the analysis, information about titleholders over a 50 year period, the countries they represent, the relationship between geo-spatial factors and selection of titleholders and hidden socio-cultural, political and economic hegemonies behind international beauty pageants were considered, paying special attention to above mentioned discourses and theories.

\section{METHODOLOGY}

\section{'Qualitative Dominant - Mixed Research Methodology' and 'Inductive Research Approach'}

In this research, a critical analysis of secondary data is undertaken using a qualitative research methodology. This study collected information relating to "cultural, political and economic hegemonies' that have influenced ideological construction of the image of 'beauty'. Consequently, a 'qualitative inductive research approach' is selected as the primary methodological approach of this research. There is a profound link between qualitative methodology and inductive research. Following inductive research process, first, data was collected using relevant secondary sources and then the findings were used inductively to formulate relevant theories, discourses, and concepts (Bryman, 2012; Thomas, 2012). While the paper relies heavily on qualitative research methodology, statistical data regarding beauty products and titleholders of a major international beauty pageant from 1967 to 2017 were used as support to validate the argument.

\section{Data collection methods}

Secondary data was extracted from a number of publications on the major international beauty pageant, beauty product industries and conceptions regarding beauty. 


\section{Analysis}

The Critical Discourse Analysis (CDA) method was used to analyze data. The data was analysed using theories and discourses described earlier in this paper (Description/ Interpretation/Explanation) (Bloor \& Bloor, 2013; Dey, 2003; May, 1997). Themes in the collected data were identified and pursued during the data analysis process (Bryman, 2012). Intensive reading, careful reading and re-reading were conducted as a procedure to identify patterns in the data (Boyatzis, 1998). A number of theories and discourses such as Feminism, Capitalism, Consumerism, Hegemonic Power and Core-peripheral Dependency guided the data analysis process.

\section{RESULTS AND DISCUSSION}

The analysis of secondary data on a major international beauty pageant's titleholders from 1967 to 2017 enabled the researchers to draw three main research findings. First, $68 \%$ of titleholders are from peripheral/semiperipheral countries (developing or under developed countries) (onlinekguide, 2017) (See Figure 1). Second, among them India, Venezuela, Brazil, Argentina and Jamaica are prominent (The Telegraph, 2017; JPP, 2017). Finally, if closely observed, the physical features of the titleholders of the last 50 years resemble the feminine beauty ideals depicting European Caucasian "white" woman (Brandstätter et al., 2003; Gross, 2006; Parameswaran, 2004), even though most of the winners of titles (68\%) are from developing regions of the world. If the organizers and judges of these pageants are guided by western images and standards of beauty, what makes them select a majority of winners from countries in the periphery? Further, the research points to the fact that when compared with the body features of an average women in a particular developing country, the titleholders from the same country show a marked difference (see Table 1). Two different theoretical approaches; first, 'cultural and political hegemony' and second, 'economic hegemony', have been used in this research to critically analyse the question of what factors influence the choice of beauty queens from a particular background in countries in the core and periphery of the world system.

\section{Cultural and political hegemony}

When previously stated arguments about the titleholders are further examined, it is noticed that the normative 'feminine beauty ideal' has been created by 'European Caucasian heterosexual male' in order to satisfy his own conceptions about 'perfect feminine beauty'. Since it is a social construction, many feminist writers have understood it as the 'myth of beauty' (Wolf, 2013). It is generally understood that, human fantasy is always based on one's own sociocultural values, beliefs and norms as well as one's living geo-political space (Jackson, 2013). Therefore, 'ideals of feminine beauty' constructed by the 'white man' depends on his personal 'conceptions of feminine beauty', 'sexual fantasies' and expectations (Leitenberg \& Henning, 1995; Wolf, 2013).

Thus, the question is why the non-European titleholders' body features and looks resemble the 'European standards of feminine beauty' rather than the 'beauty ideals' generated from within their respective cultures. If the theory of 'cultural hegemony' by Gramsci is considered here, the ruling class of capitalist countries- the European Caucasian male (the white man with economic and political power) or the 'members of a super structure with hegemonic power'- produces cultural ideologies, values and norms which satisfy their own specific expectations (Adamson, 1983; Mouffe, 2014).

Hegemonic beauty culture has normalised its own values and norms as models and had them imposed on the 'base' (southern periphery) in order to maintain their cultural hegemony (Salamini, 2014). Accordingly, the ideals of feminine beauty in European culture, which are created and maintained by the 'white man' who enjoys economic, social, cultural and political dominance within the 'super structure', have become the universal ideals of 'female beauty'.

On the other hand, the normative 'image of life' constructed through the super structural ideologies has become the model of the majority in the base (developing and underdeveloped states) and this majority has subconsciously or involuntarily accepted these 'ideological constructs' to be 'norms' (Anderson, 2017; Mouffe, 2014). Subsequently, a majority in developing or less-developed nations have configured the European/ western standards of beauty to be the universal standards of feminine beauty.

In the period under consideration, the highest number of titleholders of a major international beauty pageant were selected from India (6) and Venezuela (5) which are southern peripheral countries in the world (Miss World, 2018). India consists of a large number of ethnic groups and human races and in general, physical appearance and body features of these ethnic groups are dissimilar to European Caucasian female body types (Parameswaran \& Cardoza, 2009). However, 'fairer-skinned feminine beauty' or western constructed unrealistic female beauty ideology has emerged as a visible, accessible, and seductive marker of social status of India (Rajagopal, 2001). 


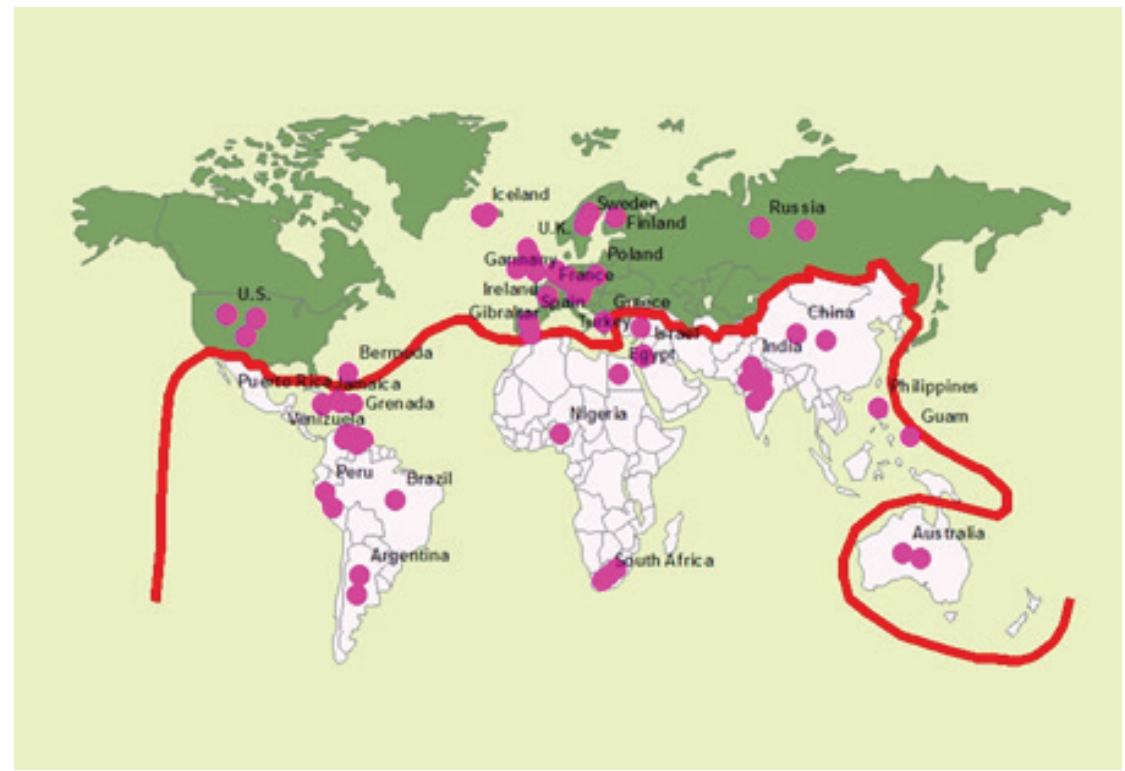

Figure 1: Spatial distribution of titleholders from 1967 to 2017

Source: Revolvy (2017)

Map by: G. P. G. Y. Dananjanie

Table 1: Profiles of randomly selected non-European titleholders

\begin{tabular}{|c|c|c|c|}
\hline Titleholder and the country & Body features & $\begin{array}{r}\text { Body features specifically of } \\
\text { the titleholders }\end{array}$ & $\begin{array}{r}\text { Body features specifically of an average woman } \\
\text { of the particular country }\end{array}$ \\
\hline \multirow[t]{5}{*}{ Titleholder 1- India } & Height & $1.7 \mathrm{~m}$ & $1.52 \mathrm{~m}$ \\
\hline & Measurements & 34-26-34 inches & - \\
\hline & Eye colour & Grey & Black \\
\hline & Hair colour & Dark brown & Black \\
\hline & Skin colour & light brown & dark or slightly dark \\
\hline \multirow[t]{5}{*}{ Titleholder 2- China } & Height & $1.77 \mathrm{~m}$ & $1.55 \mathrm{~m}$ \\
\hline & Measurements & 34-23-35 inches & - \\
\hline & Eye colour & Brown & Black \\
\hline & Hair colour & - & Black \\
\hline & Skin colour & - & Yellow tan to pale brown \\
\hline \multirow[t]{3}{*}{ Titleholder 3- Jamaica } & Height & $1.80 \mathrm{~m}$ & $1.6 \mathrm{~m}$ \\
\hline & Measurements & 36-23-37 inches & - \\
\hline & Eye colour & Brown - Dark & Black \\
\hline \multirow[t]{4}{*}{ Titleholder 4- India } & Height & $1.73 \mathrm{~m}$ & $1.52 \mathrm{~m}$ \\
\hline & Measurements & 34-26-34 inches & - \\
\hline & Eye colour & Brown & Black \\
\hline & Hair colour & Brown & dark or slightly dark \\
\hline
\end{tabular}

Sources: Revolvy (2017); Disabled World (2017); Starschanges (2018); Genvive (2018); Thestickyfacts (2018); Starsunfolded (2018) 
Indian women with matching body features to western standards of female beauty enjoy high sociocultural status and a high demand in the Indian marriage market compared to average females in the population. Below mentioned marriage advertisement in a popular English newspaper in India is a good example of the ideal under examination.

"Delhi-based affluent, high status cultured Punjabi Arora industrialist family is looking for a very beautiful, fair, slim, tall, educated, bride from cultured family for their only son" (Hindustan Times, June 23, 2002 cited in Parameswaran \& Cardoza, 2009: p. 230).

Fairness, slimness, tallness, youthfulness, long legs, and big eyes are considered standards of femininity in India (Parameswaran \& Cardoza, 2009). According to many feminists and postcolonial analysts, female beauty ideology to which Indian women are constantly subjected provides an example of postcolonial cultural dependency pattern of the developing world. This ideology is created in western countries with dominant cultural-political hegemonic power over other nations and promoted and socialized through media, advertisements and literature, and passed on to people in developing countries (Faris, 2002; Stoler, 2010; Shohat \& Stam, 2002). Especially, westernized elites of former peripheral colonies still believe in postcolonial rulers, their work and culture to be the 'best' (Picton, 2013). For example, 'pale' skin is considered to be more attractive and appealing than 'dark' skin by westernized elite in developing countries (Saraswati, 2011; Robinson, 2011). Such a rhetoric of so-called ideology of beauty has created ugly sociocultural issues within the local context of many peripheral countries. Rahman (2002) has researched on middle class Indian Hindu women in New Jersey and according to his findings, skin color, along with other such variables as caste and occupation, determined these women's access to upwardly mobile, educated and professional male spouses. As he highlighted "a darker girl is often a liability to her family. It is difficult to arrange a marriage for her. Even a dark Brahmin girl has a low value in the marriage market" (Rahman, 2002: p. 23). This is common tragedy in Venezuela (Acosta-Alzuru, 2010) as well as in many other developing countries (Dewey, 2008).

Importantly, partly due to geo-spatial circumstances, women in developing countries are marked with unique body features and identities. However, none of the titleholders from these countries represent this uniqueness. Yet, all of them are a copy of 'female beauty image' of the western world. For instance, women with European Caucasian body features or women with
Eurasian/Eurafrican origin who possess 'fairer' skin and physical features of normative European feminine beauty ideals are generally considered more beautiful/attractive. Thus, such women with abnormal features gain more public attention in Asian/African contexts relative to average native women from the same countries. Jacqueline Fernandez and Katrina Kaif with Eurasian origins are examples of this phenomenon. Jacqueline Fernandez from Sri Lanka became Miss Sri Lanka in 2006 and currently she is a popular Bollywood actress in India (Sekho, 2017). Similarly, Katrina Kaif is a popular actress in Bollywood film industry (LCB, 2017) and is considered by media as one of India's most attractive celebrities.

\section{Economic hegemony and creation of beauty}

The phenomenon of relatively high presence (68\%) of titleholders from developing countries (southern periphery) eventhough the typical European Caucasian "white" women live in developed countries in Europe and North America, can be critically analyzed using Marxist and neo-Marxist perspectives. Even though international beauty pageants every year reportedly choose the most beautiful women in the world, there is a questionable 'economic trap' involved, in that it is associated with the economic hegemony of the developed capitalist countries (Hunter, 2011, Keohane, 2005; Yang, 2011). There is a big market for the beauty products in the developing world and many multinational companies are involved in the manufacture and sale of a diverse range of beauty products (Abramowicz et al., 2011; Xie \& Zhang, 2013). International beauty pageants can be considered as huge advertisement campaigns for the beauty-care products as evident from the fact that multinational companies involved in the beauty-care industry have generously sponsored such pageants (Glenn, 2008; Hoad, 2004). A majority of non-European titleholders have been selected from the countries with high population boom in the world (see Table 2) and it is possible that 'size of the market' is a hidden factor in selecting the 'most beautiful women' in the world. This has links to economic neo-liberalism in this era. According to Jones,

"In the age of imperialism, Western and white beauty standards emerged as global ideals. This was historically contingent on the unique circumstances prevailing at that time, but once the ideals were in place, the strategies of business enterprises helped reinforce it. As the beauty companies built international markets through exporting and foreign direct investment, they diffused perceptions of beauty and not simply skin creams and lipsticks" (Jones, 2011: p. 911). 
Table 2: Demographic information about prominent non-European countries with titleholders

\begin{tabular}{lrrr}
\hline Country & $\begin{array}{r}\text { Winning } \\
\text { frequency }\end{array}$ & $\begin{array}{r}\text { Population size } \\
\text { (millions) }\end{array}$ & $\begin{array}{r}\text { World rank on } \\
\text { population }\end{array}$ \\
\hline India & 6 & 1,281 & 2 \\
Venezuela & 5 & 32.41 & 43 \\
China & 2 & 1,379 & 1 \\
Argentina & 2 & 43.85 & 32 \\
Brazil & 1 & 207 & 5 \\
Nigeria & 1 & 190 & 7 \\
\hline
\end{tabular}

Source: Central Intelligence Agency (2017); Revolvy (2017)

Yearly, a large amount of currency flows from peripheral countries to the core for beauty products and among the citizens in developing countries, famous western beauty brands have become a 'class mark' compared with similar local brands (Holt et al., 2004).

Plenty of examples can be drawn from Venezuela and India for this situation. As discovered by AcostaAlzuru, when an average young female in Venezuela was asked "What is your biggest fantasy?" the majority had the same answer "me? That I win the Miss Venezuela pageant!" (Acosta-Alzuru, 2010). However, if today's socio-economic background of Venezuela is considered, the country has suffered many economic crises during the last few decades and more than $70 \%$ of the population lives in poverty. Ignorance or lack of education is a serious issue that is associated with poverty in this country (Acosta-Alzuru, 2010). Yet, Venezuelans are ready to spend more on cosmetic products and procedures than on education (Delgado Barrios, 2006, cited in AcostaAlzuru, 2010). The nation spends fifth of their annual income to buy branded beauty products (produced by multinational companies) to modify or improve their physical appearance (Rohter, 2000).

Both Venezuela and India opened their markets for economic liberalization process at the beginning of the 1990s (Venezuela in 1989 and India in 1991) following capitalist and neo-liberal ideologies (AcostaAlzuru, 2010; Parameswaran \& Cardoza, 2009). With the reformation of economic structures of these two countries, "private/free" enterprises emerged and inaugurated to form a strong global capitalist consumer economy allowing multinational companies to enter the local market while introducing a heavy consumer lifestyle to the local community. According to Parameswaran \& Cardoza (2009), "economic liberalization process implemented in the early 90 's, centred on encouraging multinational companies to produce and market lifestyle commodities to India's burgeoning middleclass consumers". A national survey conducted in 1996 revealed that,

"a majority of those surveyed (South Asian middle and lower middle consumer class) had expressed a "ravenous appetite" for clothing, auto mobiles, fast food, wrist watches, and cosmetics, higherorder commodities that signalled a widespread desire for upward mobility" (Parameswaran \& Cardoza, 2009: p. 216-217).

With the implementation of neo-liberal economic policy and free trade, a large number of multinational companies which manufacture exclusive brands of beauty products involved to reach out to huge markets (Parameswaran and Cardoza, 2009). This situation is common in Venezuela as well as in many other developing countries (Acosta-Alzuru, 2010). Most importantly, $95 \%$ of these 'so-called' exclusive branded beauty products are manufactured and distributed by multinational companies of which the headquarters are geo-spatially located in capitalist developed countries (see Figure 2). Manufacture of these beauty care products has played a prominent role in idealizing the myth that one needs to be fair to be beautiful, and vice versa while internalizing the same myth in the minds of the majority of unsophisticated South Asian middle and lower middle consumer class. Similarly, they further promote this myth through international beauty pageants and thus, market their cosmetic and skin care production to nonEuropeans as means of becoming 'fair' and 'beautiful' while getting rid of or at least minimizing the 'stigma' of being 'dark-skinned' and 'ugly'. 
It should not be neglected that the titleholders from India and Venezuela have won the titles after 1980s and two underlying factors behind this selection can be observed. First, both countries have opened their economies after the 1980s based on neo-liberal ideologies and consequently multinational companies manufacturing exclusive brands of beauty products entered the territorial boundaries of these countries. As a part of expanding their markets in these countries, these companies have promoted and sponsored beauty pageants within the country and worldwide. Then, a number of titleholders have been selected from contexts where they could help create a big market for their products. For example, an international beauty pageant titleholder from India, who won the title in early 1990's, has graced the pages of many magazines to the advertisements of expensive cosmetics. Her brand of beauty- very light skin, thin nose, full pink lips, and almond-shaped large green eyes- captures the standards of contemporary Indian beauty and many females of India are subconsciously attracted to the relevant brands (Parameswaran \& Cardoza, 2009).

Second, a link between the size of human population in these developing countries and the selection of titleholders can be established. For example, countries such as India, Brazil, Venezuela and Nigeria represented by a major international beauty pageant's titleholders are the top world ranking countries in population size (see Table 2); that is, both neo-liberal free trade economic policies of these countries and their population size have become a hidden criterion in the selection of titleholders from these southern peripheral countries.

Exclusive branded beauty products have annually cost a large amount of money from people, especially women from developing countries (see Table 3) (Jones, 2011). When this economic trap behind international beauty pageants is analysed, it is clear that ideology of construction of 'beauty' is not as beautiful as it looks. According to Žižek, behind the veil of Western liberalcapitalism, there is 'obscenity and corruption' (Butler et al., 2000; Zizek, 2011) and global international beauty pageants are good examples to prove this statement.

Most mainstream beauty pageants have very strict ideals of beauty, and winners have often been falsely glorified for their beauty. These events lack "uniqueness" and "specialty" among the contestants who have been forced to accept an "unrealistic" beauty image which is rather an "unattainable" ideal for most women in these peripheral regions. This situation can be explained in relation to McDisneyization of contemporary society- the combination of two concepts of Disneyization (Bryman, 1999) and McDonaldization (Ritzer, 1983). The four trends outlined in this Disneyization, namely, theming, dedifferentiation of consumption, merchandizing and emotional labour, can hugely influence the shape and content of people. For instance, use of winners of beauty pageants in promotion campaigns of exclusive

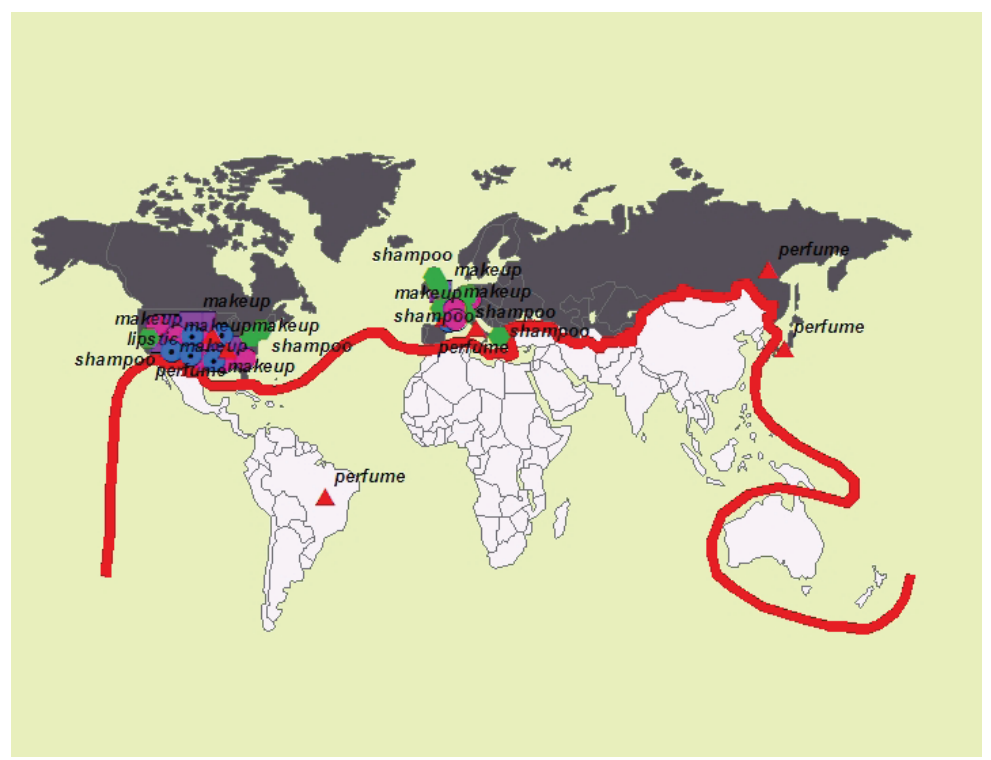

Figure 2: Spatial distribution of the headquarters of biggest beauty-care companies

Source: Revolvy (2017)

Map by: G. P. G. Y. Dananjanie 
Table 3: Location of top 20 global beauty companies and their annual income of 2016

\begin{tabular}{lrr}
\hline Rank of the company based on income & Location of headquarters & Annual income (US \$ billion) \\
\hline 1 & France & 27.6 \\
2 & UK & 22.3 \\
3 & USA & 18 \\
4 & USA & 11.3 \\
5 & USA & 10.7 \\
6 & USA & 7.1 \\
7 & Japan & 6.3 \\
8 & Germany & 6 \\
9 & Japan & 5 \\
10 & France & 5 \\
11 & South Korea & 4.8 \\
12 & USA & 4.6 \\
13 & USA & 4.4 \\
14 & USA & 4.3 \\
15 & Germany & 4.2 \\
16 & USA & 4 \\
17 & France & 2.9 \\
18 & Japan & 2.2 \\
19 & Brazil & 2 \\
\hline & USA & 1.9 \\
\hline
\end{tabular}

Source: Redding (2017)

beauty care brands or advanced technologies in beauty surgeries, reflects "differentiation of consumption where consumption of disparate sphere becomes intertwined" (Warde, 2005). Additionally, these events are organized in an emotionally satisfying/appealing manner that "distract the consumer from realizing that they are being captivated into an artificially constructed themed environment and pitched the sale of goods" (Bryman, 1999: p. 380). Ritzer's concept of McDonaldization can be used to understand and analyse this situation further (Ritzer, 1998; 1983; 2003). According to Ritzer, McDonaldization is a process of rationalization but, rational systems can even be irrational,

"that means rational systems are unreasonable and dehumanizing systems which deny humanity, human reasoning of the people who work within them or are served by them" (Ritzer 1994: p. 154).

It is no wonder that in a globalized and capitalized world, fashion and cosmetic industries increase their sales by emotionally exploiting women in the contemporary society by utilizing an "unrealistic" stereotypical ideology of beauty which "operates by transforming ideal beauty into a timeless and universal standard towards which "ideal women should strive" (Gallagher $\&$ Hebert, 2007).

\section{CONCLUSION}

The research thus concludes that 'beauty' is a creation of vested interests in the capitalist world. Moreover, standards of beauty are constructed and ideologies and concepts regarding 'feminine beauty' are shaped by world cultural, political and economic hegemonies. Specially, capitalism of this era has played a dominant role in forming these concepts and ideologies in order to create 'market monopolies' deprived of a rational production or consumption system. Instead of producing rational goods and services for human, capitalist process has attended to exploit people's emotional values and feelings through 'fantasies' in order to create markets, especially in southern peripheral countries. This kind of market monopolies and ideological creations can negatively contribute in three ways. First, such irrational markets, which support to maintain global core-peripheral dependency can become a barrier to developing countries to achieve their own development targets. Second, this can result in socio-cultural marginalisation of people who do not represent the hegemonic core. Finally, an 
economic boom based on such market monopolies does not contribute to sustainable development as it is not based on a rational production system.

\section{ACKNOWLEDGMENT}

Authors would like to thank G. P. G. Y. Dananjanie (cartographer), Sumudu Walakuluge and the reviewers who helped to improve this paper.

\section{REFERENCES}

Abramowicz, H., Abt, I., Adamczyk, L., Adamus, M., Aggarwal, R., Antonelli, S. and Aushev, Y. (2011) Measurement of beauty production in deep inelastic scattering at HERA using decays into electrons, The European Physical Journal C, 71(2), p. 1573 .

DOI: https://oi.org/10.1140/epjc/s10052-011-1573-x

Acosta-Alzuru, C. (2010) Beauty queens, machistas and street children: the production and reception of socio-cultural issues in telenovelas, International Journal of Cultural Studies, 13(2), pp: 185-203.

DOI: https://doi.org/10.1177/1367877909356719

Adamson, W. L. (1983) Hegemony and revolution: a study of Antonio Gramsci's political and cultural theory, California, USA: University of California Press.

Althusser, L. (1977) Ideology and ideological state apparatuses (Notes towards an investigation), In Althusser L., Lenin and Philosophy and other essays, London, UK: New Left Books.

Althusser, L. (2006) Ideology and ideological state apparatuses (Notes towards an investigation), The anthropology of the state: a reader, 9(1), pp: 86-98.

Anderson, P. (2017) The Antinomies of Antonio Gramsci, London.UK: Verso Books.

Aronowitz, S. (2016) The crisis in historical materialism: Class, politics and culture in Marxist theory, Berlin, Germany: Springer.

Baudrillard, J. (2016) The consumer society: myths and structures, London, UK: Sage publication.

Bauman, Z. (2004) Work, consumerism and the new poor, Columbus, USA: McGraw-Hill Education.

Bloor, M. \& Bloor, T. (2013) The practice of critical discourse analysis: an introduction, London, UK: Routledge.

DOI: https://doi.org/10.4324/9780203775660

Bordo, S. (1993) Unbearable Weight: Feminism, Western Culture and the Body, Berkeley, CA: University of California Press.
Boyatzis, R. E. (1998) Transforming qualitative information: thematic analysis and code development, London, UK: Sage.

Brandstätter, A., Parsons, T. J. \& Parson, W. (2003) Rapid screening of mtDNA coding region SNPs for the identification of west European Caucasian haplogroups, International Journal of Legal Medicine, 117(5), pp: 291-298.

DOI: https://doi.org/10.1007/s00414-003-0395-2

Brydon, D. (2004) Postcolonialism now: autonomy, cosmopolitanism, and diaspora, University of Toronto Quarterly, 73(2), pp: 691-706.

DOI: https://doi.org/10.3138/utq.73.2.691

Bryman, A. (1999) The Disneyization of society, The Sociological Review, 47(1), pp: 25-47.

DOI: https://doi.org/10.1111/1467-954X.00161

Bryman, A. (2012) Social research methods, $4^{\text {th }}$ Ed., Oxford, UK: Oxford University Press.

Butler, J., Laclau, E. \& Žižek, S. (2000) Contingency, hegemony, universality: Contemporary dialogues on the left, London, UK: Verso.

Butler, J (1993) Bodies That Matter: on the discursive limits of “sex", London, UK: Routledge.

Central Intelligence Agency (2017) Country comparison, [Online] Available from: https://www.cia.gov/library/ publications/the-world-factbook/rankorder/2119rank.html [Accessed: $7^{\text {th }}$ October 2018].

Cheng, A. A. (2000) Wounded Beauty: an exploratory essay on race, feminism, and the aesthetic question, Tulsa Studies in Women's Literature, 19(2), pp: 191-217.

DOI: https://doi.org/10.2307/464426

Conway, D. \& Heynen, N. (2002) Classical dependency theories, from ECLA to Andre Gunder Frank, In Desai, V. \& Potter, R. B. (Eds.) The companion to development studies, pp: 97-101, London, UK: Oxford University Press.

Costantinos, B. T. (1998) An overview of development theories, Addis Abeba, Ethiopia: The Centre for Human Environment.

d'Hauteserre, A-M. (2004) Postcolonialism, colonialism, and tourism, In Lew, A. A., HallC. M. \& Williams, A. M. (Eds.) A companion to tourism, pp: 235-245, Oxford, UK: Blackwell Publishing.

DOI: https://doi.org/10.1002/9780470752272.ch19

de Beauvoir, S. (2014) The second sex, NY, USA: Random House.

Desai, V. \& Potter, R. B. (Eds.) (2014) The companion to development studies, $3^{\text {rd }}$ Ed., Oxford, UK: Routledge. 
Deutscher, P. (2014) How to read Derrida, London, UK: Granta Books.

Dewey, S (2008) Making Miss India Miss World: Constructing gender, power, and the nation in postliberalization India, New York, USA: Syracuse University Press.

Dey, I. (2003) Qualitative data analysis: A user-friendly guide for social scientists, London, UK: Routledge.

DOI: https://doi.org/10.4324/9780203412497

Dirlik, A. (1994) The postcolonial aura: Third world criticism in the age of global capitalism, Critical Inquiry, 20(2), pp: 328356.

DOI: https://doi.org/10.1086/448714

Disabled World (2017) Height Chart of Men and Women in Different Countries [Online] Available from: https://www. disabled-world.com/artman/publish/height-chart.shtml [Accessed: $6^{\text {th }}$ October 2018].

Dubuisson, D. (2003) The western construction of religion: myths, knowledge, and ideology, Maryland, USA: JHU Press.

Elden, S. (2016) Space, knowledge and power: Foucault and geography, London, UK: Routledge.

DOI: https://doi.org/10.4324/9781315610146

Faris, J. C. (2002) The gaze of western humanism. The Antropology of Media. A Reader, Malden, Oxford: Blachwell Publishers, pp: 77-91.

Featherstone, M. (1982) The body in consumer culture, Theory, culture \& society, 1(2), pp: 18-33.

DOI: https://doi.org/10.1177/026327648200100203

Fewel, G. R. (1981) A socialist model of economic development: the Polish and Bulgarian experiences, World Development, 9(9), pp: 929-950.

DOI: https://doi.org/10.1016/0305-750X(81)90050-4

Forbes, G. B., Collinsworth, L. L., Jobe, R. L., Braun, K. D. \& Wise, L. M. (2007) Sexism, hostility toward women and endorsement of beauty ideals and practices: are beauty ideals associated with oppressive beliefs?, Sex Roles, 56(5-6), pp: 265-273.

DOI: https://doi.org/10.1007/s11199-006-9161-5

Foster, J. B. (2001) Ecology against capitalism, Monthly Review, 53(5), pp: 2-3.

DOI: https://doi.org/10.14452/MR-053-05-2001-09_1

Foster, J. B., Clark, B. \& York, R. (2011) The ecological rift: Capitalism's war on the earth, New York, NY: NYU Press.

Gallagher, A. H. \& Pecot-Hebert, L. (2007) "You Need a Makeover!": The Social Construction of Female Body Image in "A Makeover Story", "What Not to Wear", and "Extreme Makeover”, Popular Communication, 5(1), pp: 57-79.
Genvive (2018) Yu Wenxia - Miss World 2012 from China [Online] Available from: https://geniusrevive.com/en/wenxia-yu-miss-world-2012-from-china/ $\quad$ Accessed: $7^{\text {th }}$ October 2018].

Glenn, E. N. (2008) Yearning for lightness: transnational circuits in the marketing and consumption of skin lighteners, Gender \& society, 22(3), pp: 281-302.

DOI: https://doi.org/10.1177/0891243208316089

Gross, A. J. (2006) The Caucasian cloak: Mexican Americans and the politics of whiteness in the twentieth-century southwest, Geo. LJ, 95, pp: 95-337.

Grosz, E. (1994) Volatile bodies: toward a Corporeal Feminism, Bloomington, USA: Indiana University Press.

Hall, C. M. \& Tucker, H. (Eds.) (2004) Tourism and postcolonialism: contested discourses, identities and representations, London, UK: Routledge.

DOI: https://doi.org/10.4324/9780203392270

Hancké, B., Rhodes, M. \& Thatcher, M. (2008) Beyond varieties of capitalism: conflict, contradictions, and complementarities in the European economy, Oxford, UK: Oxford University Press.

Hoad, N. (2004) World piece: what the Miss World pageant can teach about globalization, Cultural Critique, 58(1), pp: 5681.

DOI: https://doi.org/10.1353/cul.2004.0024

Holt, D. B., Quelch, J. A. \& Taylor, E. L. (2004) How global brands compete, Harvard Business Review, 82(9), pp: 68-75.

Hunter, M. L. (2011) Buying racial capital: skin-bleaching and cosmetic surgery in a globalized world, The Journal of Pan African Studies, 4(4), pp: 142-164.

Jackson, R. (2013) Fantasy, London. UK: Routledge.

DOI: https://doi.org/10.4324/9781315015958

Jameson, F. (2009) Valences of the Dialectic, Landon, UK: Verso.

Jones, G. (2011) Globalization and beauty: a historical and firm perspective, EurAmerica, 41(4).

JPP (2017) Information courtesy of Miss Universe [Online] Available from: http://www.misshongkongpageant.com/ universelist.htm [Accessed: $6^{\text {th }}$ October 2018].

Karacan, E. (2007) Women under the hegemony of body politics: fashion and beauty, MSc., Middle East Technical University, Ankara, Turkey.

Keohane, R. O. (2005) After hegemony: cooperation and discord in the world political economy, Princeton. USA: Princeton University Press. 
Krishna, S. (2009) Globalization and postcolonialism: hegemony and resistance in the twenty-first century, Lanham, MD: Rowman \& Littlefield.

LCB (2017) The complete biography of Katrina Kaif [Online] Available from: http://www.lightscamerabollywood.com/thecomplete-biography-of-katrina-kaif/ $\quad$ Accessed: $6^{\text {th }}$ October 2018].

Leitenberg, H. \& Henning, K. (1995) Sexual fantasy, Psychological bulletin, 117(3), p. 46.

DOI: https://doi.org/10.1037/0033-2909.117.3.469

Li, M. (2009) Capitalism, climate change and the transition to sustainability: alternative scenarios for the US, China and the world, Development and Change, 40(6), pp: 1039-1061.

DOI: https://doi.org/10.1111/j.1467-7660.2009.01611.x

Marcuse, H. (2013) One-dimensional man: studies in the ideology of advanced industrial society, London, UK: Routledge.

DOI: https://doi.org/10.4324/9780203995211

May, T. (1997) Social research: Issues, methods, and process $\left(2^{\text {nd }}\right.$ Ed.) Philadelphia, PA: Open University Press.

Micheletti, M. \& Stolle, D. (2008) Fashioning social justice through political consumerism, capitalism, and the internet, Cultural Studies, 22(5), pp: 749-769.

DOI: https://doi.org/10.1080/09502380802246009

Miss World (2018) Miss World competition [Online] Available from: https://www.missworld.com/\#/competition [Accessed: $7^{\text {th }}$ October 2018].

Mouffe, C. (2014) Gramsci and Marxist Theory (RLE: Gramsci), London.UK: Routledge.

Muller, J. Z. (2007) The mind and the market: Capitalism in western thought, New York, NY: Random House LLC.

onlineGKguide (2017) List of Miss Universe Titleholders from 1952 to till now [Online] Available from: https://www. onlinegkguide.com/list-of-miss-universe-winners-by-year/ [Accessed: $5^{\text {th }}$ October 2018].

Parameswaran, R. (2004) Global queens, national celebrities: tales of feminine triumph in post liberalization India, Critical Studies in Media Communication, 21(4), pp: 346-370.

DOI: https://doi.org/10.1080/0739318042000245363

Parameswaran, R. \& Cardoza, K. (2009) Melanin on the margins: advertising and the cultural politics of fair/light/white beauty in India, Journalism \& Communication Monographs, 11(3), pp: 213-274.

DOI: https://doi.org/10.1177/152263790901100302
Picton, O. (2013) The complexities of complexion: a cultural geography of skin colour and beauty products, Geography, 98, p. 85 .

Rahman, R. B. (2002) Color as a status: the role of skin color among Hindu Indian women, Department of Sociology, Rutgers University.

Rajagopal, A. (2001) Politics after television: Hindu nationalism and the reshaping of the public in India, Cambridge University Press.

Redding, M (Beauty Packaging?) (2017) Top 20 Global Beauty Companies [Online] Available from: https://www. beautypackaging.com/issues/2016-10-01/view_features/top20-global-beauty-companies-688974 [Accessed: $6^{\text {th }}$ October 2018].

Revolvy (2017) List of Miss World Titleholders [Online] Available from: https://www.revolvy.com/topic/List $\% 20$ of $\% 20$ Miss\%20World\%20titleholders [Accessed: $4^{\text {th }}$ October 2018].

Ritzer, G. (1983) The "McDonaldization" of society, The Journal of American Culture, 6(1), pp: 100-107.

DOI: https://doi.org/10.1111/j.1542-734X.1983.0601_100.x

Ritzer, G. (1998) The McDonaldization thesis: Explorations and extensions, California, USA: Sage.

Ritzer, G. (1994) Sociological Beginnings on the Origins of Key Ideas in Sociology, New York, USA: McGraw-Hill.

Ritzer, G. (2003) Islands of the living dead: The social geography of McDonaldization, American Behavioral Scientist, 47(2), pp: 119-136.

DOI: https://doi.org/10.1177/0002764203256179

Robinson, P. A. (2011) Perceptions of beauty and identity: the skin bleaching phenomenon in Jamaica, Adult Education Research Conference, Kansas State University [Online] Available from http://newprairiepress.org/aerc/2011/papers/85 [Accessed: $5^{\text {th }}$ October 2018].

Rohter, L. (2000) Who is vainest of all, New York Times, 13, pp: $1-10$.

Salamini, L. (2014) The Sociology of Political Praxis (RLE: Gramsci): An Introduction to Gramsci's Theory, London, UK: Routledge.

DOI: https://doi.org/10.4324/9781315794365

Saraswati, L. A. (2011) Why Beauty Matters to the Postcolonial Nation's Masters: Reading Narratives of Female Beauty in Pramoedya's Buru Tetralogy, Feminist Formations, 23(2), pp: $111-131$

DOI: https://doi.org/10.1353/ff.2011.0025 
Sarkar, S. (2014) Media and women image: a Feminist discourse, Journal of Media and Communication Studies, 6(3), p. 48.

DOI: https://doi.org/10.5897/JMCS2014.0384

Sekho (2017) Jacqueline Fernandez Family History Photos Father Mother Members Name, [Online] Available from: http://sekho.in/jacqueline-fernandez-family-history-photosfather-mother-members-name/ [Accessed: $5^{\text {th }}$ October 2018].

Shohat, E. and Stam, R. (2002) The imperial imaginary, In Askew, K. and Wilk, R. R. (Eds.) The anthropology of media: A reader, Oxford: Blackwell, pp: 117-147.

Stark, R. (2007) The victory of reason: how Christianity led to freedom, capitalism, and western success, New York, NY: Random House LLC.

Starschanges (2018) Aishwarya Rai [Online] Available from: https://starschanges.com/aishwarya-rai-height-weight-age/ [Accessed: $6^{\text {th }}$ October 2018].

Starsunfolded (2018) Manushi Chhillar [Online] Available from: https://starsunfolded.com/manushi-chhillar/ [Accessed: $6^{\text {th }}$ October 2018].

Stoddart, M. C. (2007) Ideology, hegemony, discourse: a critical review of theories of knowledge and power, Social Thought \& Research, pp: 191-225.

DOI: https://doi.org/10.17161/STR.1808.5226

Stoler, A. L. (2010) Carnal knowledge and imperial power: race and the intimate in colonial rule, California, USA: University of California Press.

Sturken, M. and Cartwright, L. (2001) Practices of looking, Oxford: Oxford University Press.

Synnott, A. (1990) Truth and goodness, mirrors and masks Part II: s sociology of beauty and the face, British Journal of Sociology, pp: 55-76.

DOI: https://doi.org/10.2307/591018

Syrotinski, M. (2007) Deconstruction and the postcolonial: at the limits of theory, Volume 2, Liverpool, UK: Liverpool University Press.
Thestickyfacts (2018) Interesting Facts about Lisa Hanna [Online] Available from: https://thestickyfacts.com/lisa-hannafacts/ [Accessed: $4^{\text {th }}$ October 2018].

The Telegraph (2017) The surprising country that has provided the most Miss World winners [Online] Available from: http:// www.telegraph.co.uk/travel/maps-and-graphics/countrieswith-most-miss-world-winners/ [Accessed: $4^{\text {th }}$ October 2018].

Thomas, L. J. (2012) Neoclassical development theory and the prebisch doctrine: a synthesis, American Economist, 38(1), pp: 75-81.

DOI: https://doi.org/10.1177/056943459403800110

Tseëlon, E. (1995) The Masque of Femininity, London, Tousand Oaks \& New Delhi: Sage Publications.

Tseëlon, E. (1993) The ideology of beauty, In Stam, H. J., Mos, L., Thorngate, W. and Kaplan, B. (Eds.) Recent trends in theoretical psychology, pp: 319-323, New York: Springer.

DOI: https://doi.org/10.1007/978-1-4612-2746-5_29

Veblen, T. (1899-2005) The theory of the leisure class; an economic study of institutions, New Delhi, India: Aakar Books.

Weitz, Rose. (Ed.) (1998) The Politics of Women's Bodies: Sexuality, Appearance and Behavior, New York, USA: Oxford University Press.

Wolf, N. (2013) The beauty myth: how images of beauty are used against women, NY. USA: Random House.

Xie, Q. and Zhang, M. (2013) White or tan? A cross-cultural analysis of skin beauty advertisements between China and the United States, Asian Journal of Communication, 23(5), pp: 538-554.

DOI: https://doi.org/10.1080/01292986.2012.756046

Yang, J. (2011) Nennu and shunu: gender, body politics, and the beauty economy in China, Signs: Journal of Women in Culture and Society, 36(2), pp: 333-357.

DOI: https://doi.org/10.1086/655913

Ziai, A. (2011) Postcolonialism and development: disparate tales reconsidered, Development and Change, 42(5), pp: 12971306.

DOI: https://doi.org/10.1111/j.1467-7660.2011.01731.x

Zizek, S. (2011) Living in the end times, London, UK: Verso. 